\title{
INFLUENCE OF THE SOCIALIST IDEOLOGY ON THE CONCEPTION OF MULTI-FAMILY HOUSING: NEW URBAN LANDSCAPE AND THE TYPOLOGICAL MODELS OF HOUSING UNITS
}

UDC 728.2 (497.11 Beograd)

\author{
Jelena Ristić Trajković ${ }^{1}$, Danica Stojiljković ${ }^{2}$ Verica Međo ${ }^{1}$ \\ ${ }^{1}$ University of Belgrade, Faculty of Architecture, Serbia \\ ${ }^{2}$ University of Belgrade, Institute for Multidisciplinary Research, Serbia
}

\begin{abstract}
The paper explores the ideological influences in the period of the socialist system on the new urban landscape, and also on design of the typological models of residential units built in Belgrade. After the Second World War, one of the main policy goals of socialism was to solve the housing problems of Belgrade, by building the modern, serially manufactured and economical housing architecture. The period of intensive construction of housing architecture of Belgrade in the period of socialist self-management is primarily related to the achieved quality of housing in this period in terms of environment humanization and functional organization of housing units. This paper explores new concepts and principles of housing architecture with the emphasis on the impact of spatial-functional apartment transformation on the family lifestyle and the formation of a new socialist culture of dwelling. Since the problem of housing is interdisciplinary, the transformation is studied out through detecting the relations of cause and effect among ideological social changes, culture of habitation, technical and technological criteria and functional-spatial house structure. The modern housing urbanism and architecture has become a representation of social, political, economic, demographic and cultural changes of the period.
\end{abstract}

Key words: multi-family housing, socialist ideology, environment humanization, urban landscape, dwelling culture, Belgrade

Received July 18, 2015 / Accepted September 16, 2015

Corresponding author: Jelena Ristic Trajkovic, Faculty of Architecture, University of Belgrade,

11000 Belgrade, Bulevar Kralja Aleksandra br. 73/II, Serbia

E-mail: arch.jelena.ristic@gmail.com 


\section{INTRODUCTION}

The form and structure of housing is primarily conditioned by social-political and economic circumstances, housing culture as well as the construction technology. In the context of ideology, an analysis of a housing unit should be observed as a category of the standard and conditions of living, a class-social category, as well as a category of economizing in a sense of general urbanization. The hierarchy of these categories depends on the social structure and social classes' understanding. In the conditions of a socialist society, all the above mentioned categories were mainly integrally present and expressed in the notion of the housing policy.

This paper researches housing concepts as a representation of the policy of decentralization and the context of the self-management socialism ideology in Yugoslavia. In the period between the two world wars, not a single settlement or a larger urban area of housing with modern, serially built, economic apartments was built in Belgrade. Only in the socio-political conditions after the Second World War was it possible to achieve this goal and find a solution to the housing issue in Belgrade. Without any previous examples which might have served as models to rely on, the postwar architecture was forced to create new concepts of housing construction from the very beginning, which completely followed the given economic and social conditions of the new socialist state. [1] The most of the changes within the architectural practice came out from ideological aspirations and can be seen primarily in the context of housing concepts and typologies, as well as in the aspects of the environment humanization. The paper also analyzes the development of the apartment in view of its "content and concept", and emphasizes the influence of the transformation of the spatial-functional structure of the apartment on a family's life, i.e. on the formation of a new socialist culture and a style of living.

\section{SOCIALIST IDEOLOGY AND HOUSING}

\subsection{The housing policy in the context and conditions of forming a socialist ideology}

The fundamental starting-point of the housing policy in self-management socialism was that the free market's mechanisms were the main source of social inequalities, and that private ownership was the primary basis of exploitation. As Blagojević mentions, one's right to an apartment was universal, as a belonging to the society as a whole, and was related to the ideal of a just distribution. Such a housing policy was specific in that the housing sector was exclusively treated as the consumption sector, however not as the production sector, which resulted in huge budgetary expenses and disparities between the needs and the economic possibilities. Vujović emphasizes the fact that the distribution of apartments in socialism was necessary for the social-ideological reproduction of the state's and the party's bureaucratic apparatuses, and that it represented a powerful factor of the apparatus's loyalty to the regime. [2] The state and its agents played a role of an investor, producer/constructor and distributer of apartments, whereas the public rental sector was supposed to be dominating over the housing fund. By abolishing the municipal funds for housing construction in the year 1965, and by changing the system of the financing of housing construction, the special-purpose contribution is left to labor organizations. Due to that, the status of the labor organization became measurable in percentage points of how well such organizations managed to accommodate, in the sense of housing accommodation, their employees. [3] Having in view the system of housing investments, i.e. the regime of 
salaries and the fact that the population of the SFRY was predominantly employed with state-owned enterprises, the provision of an apartment owned by the state or sociallyowned was the only one socially efficient solution in the cases of all households. As all the other socialist cities Belgrade was faced with a problem of the constant lack of housing units, so the fact that one's having a apartment of their own became a matter of one's prestigious position and social stratification was a paradox of the housing policy of self-management socialism.

\subsection{The ideology of the "minimizing of the maximum" standard}

In the 1950's, housing construction was becoming a priority. The imperative of the housing policy in this period was to build as large a number of apartments as possible to solve the overall housing issue. The consequence of such social circumstances was an abrupt fall in the standard of housing as compared with the pre-war one. The housing consumption standards in the state's rental sector were treated as ideological, with an aim to control inequality. A maximum number of square meters per individual were being prescribed without a possibility of its exceeding (the minimizing of the maximum); however, it was not the case with the minimum, which is much more significant from the standpoint of the satisfaction of needs. For the new working class who were the foundation of the society, it was necessary to provide apartments in accordance with equal minimal standards of living. [4] Such a social role of the state in the field of housing is contrary to the approach of the "maximizing of the minimum" (whose increase is always sought) in market systems.[3] Year after year, continuously, the square meters of the housing space were being reduced per citizen in Belgrade. Between the years 1946 and 1949, the housing floor area per citizen declined from $11 \mathrm{~m} 2$ to $9.8 \mathrm{~m} 2$. If compared with the pre-wartime $13.9 \mathrm{~m} 2$ of the housing floor area per citizen, that decline was a rather obvious one. The reduction was progressively continued till $6.5 \mathrm{~m} 2$ of the housing floor area per citizen in Belgrade in the year 1958. Having in view the estimation presented by French sociologists (the pathological threshold below which it is not possible to go without psycho-physical disturbances is between 8 and $10 \mathrm{~m} 2$ per individual) these data indicate how dramatic the housing situation in Belgrade was in this time period. [5]

A big problem in the field of the housing standard was too expensive construction. In order to solve the problem, various proposals were being made. Some of the most extreme attempts were certainly unsuccessful experiments in constructing apartments without the water supply system and other installations. In the context of the analysis of the mentioned proposal, a data which is deemed significant is that, in the year 1956, only around one-third of apartments in Belgrade were built with a bathroom. [6] In order to reduce the costs of construction, numerous people's committees were prohibiting the use of tiles and the installation of boilers in apartments. However, it is the fact that, irrespective of their being modestly constructed, the apartments built in that time period exceeded the economic power of the country. A significant increase in the standard in housing construction was present during the 1970's and the 1980's, when the majority of the apartments were being built for the army's needs. In that time period, differently from the modest postwar housing solutions of social apartments, a significant number of built housing facilities reached the high housing standard category from the point of view of their program quality, organization, function, content and equipment. [7] 


\subsection{The concept of the "elite" family living of the socialist citizen in collective housing conditions}

The socialist system of the production of social life and the social standard also conditioned a specific manner of the "production" of the universal housing space. Facilities mass construction in the regime of collective housing and the system of prefabricated construction, were being presented as the most economic and the most rational of all manners for reaching a higher living standard and for forming a new culture of collective multi-family housing.

The concept of the housing unit in the socialist system went through a transformation of the cultural and urban characters, evolving from modest postwar housing solutions related to the social housing units intended to the regime of social distribution to superior products of competition-induced solutions - which reach the high living standard category once their program quality, organization, function, content and pieces of equipment are taken into consideration, and as such represent a sort of a public good. [7] As a consequence of such a policy, a large fund of Belgrade's housing architecture was designed, later constructed as well, in the time period of an intensive competition activity between 1966 and 1975, exactly as a result of the competition-induced solutions. Architectural-urban competitions were being carried out because of a need to reach an appropriate, expected, qualitative and quantitative level of the standardization of the housing space.

In the specified time period, the largest number of apartments were being built on the territory of New Belgrade, first of all for the needs of the Army. [8] After the positive experience related to the realization of the construction of the army's apartments in Block 21, a conclusion was that, for future housing construction, it was needed to increase the apartment floor area (three-room and bigger apartments), so that the central zone of New Belgrade should became "elite" in its character. Once the realization of these facilities had been brought to an end (having lasted from the year 1972 to the year 1976), the housing construction in New Belgrade reached on average $40 \%$ of the overall housing construction on the territory of Belgrade, [9] having an influence on the standard of housing construction as well as on an increase in the average floor area and structure of housing units at the level of the city. This fact was, first of all, influenced by the fact that the Army was relatively independent in making choice of a location, which certainly represented a reflection of its social position and status.

\subsection{The concept of "self-creation" - a utopian model of housing megablocks}

Along with the establishment of new habits and the increased living standard in the 1960s in Yugoslav society also began the emergence of criticism of functionalist architecture that had sought to standardize residential architecture with the aim of equalizing social values and providing each individual the same living conditions. Such a critical approach followed contemporary international tendencies, which can be seen in the quest to satisfy the needs of a pluralistic society. To quote Hercberger, "what we must look for, in place of prototypes which are collective interpretations of individual living patterns, are prototypes which make individual interpretations of the collective patterns possible; in other words, we must make houses alike in a particular way, such that everyone can bring into being his one interpretation of the collective pattern." [10] The question arising from this is,why it is necessary to create space for an unknown family with no relation to the object or indeed the ability of individualization. Criticizing modern urbanism that created the object as a summation of apartments incorporated in a schematic volume, discarding regional, national and personal 
creative preoccupations, socialist architects developed new housing concepts that indicated values of an active relationship between people-creator-user. In this sense, the architectural aspirations were diverted towards entrusting the arrangement of the apartment to the user, his desires, hobbies, needs and tastes. This approach is possible only if there is a common unifying concept of the city, conceptualized by the architect-urbanist, while the arranging of housing units is left to the individual user, in accordance with the idea of "self-creation". These concepts, at the time of their inception, were not able to bring about the implementation of the theoretical system due to the constraints of the construction industry and housing construction practices.

\section{NEW RESIDENTIAL LANDSCAPE AND TENDENCY TOWARDS ENVIRONMENT HUMANIZATION}

\subsection{The ambiance of the new urban landscape}

The ambiance of housing architecture is constituted by rituals and routines of everyday life. As such, housing architecture is very suitable for the transmission and presentation of new ideas and new transformations of society. Post-war construction of cities that went hand in hand with the transformation of Yugoslavia into an industrial society and included mass migrations from rural areas to cities, provided a new concept of everyday life evident in the multisensory experience of the ambiance of the modern settlements. The glorification of socialist ideology required big projects and a whole new urban landscape as a model to follow, to give the modern city what termed "structure of feeling." [11] That new sort of urban philosophy drew on the idea that a whole new set of spatial experiences was needed. All the principles of socialist ideology were supposed to become apparent in the experience of the atmosphere of the new environment. The role of architectural ambience was to produce architectural space that articulates the experience of our "being-in-the-world" and strengthens our sense of reality and self. As such, modernist ambience had a significant role in the transmission of social principles and ideas.

The most important characteristic of ambiance of a modernist city were the large-scale urban transformations, which was in line with the new ideas of progressivist society epitomized by massive construction and prefabrication. Essential to this was the perception of architecture as volume rather than mass, as well as its regularity and avoidance of extraneous ornamentation. These architectural elements were followed by a strong socialist ideology of society and ideas of modern life. In accordance with this ambiance of modernity, socialist housing architecture was formed somewhere between these architectural projects and the new lifestyle, in order to support the idea of a new society through a new concept of architecture. In the words of Christian Hermansen Cordua, this was the context for the development of urban discourse characterized by a dialectic exchange between the realms of the ideal and the practical. [12] This dialectic was played out in large metropolitan areas, which were the sites for the formation of modernity.

\subsection{Modern city criticism and humanization of environment}

When we talk about the ambience of the modern city on the example of planning and construction of New Belgrade, we can see the obvious tendency to create a new society oriented towards a more humane environment. The ideology of modern movement in New 
Belgrade development was promoted through the vision of a new, clean and healthy city and application of new modern technologies. The elementary structural model of the New Belgrade functional city concept was open block which included freestanding structures surrounded by greenery, and rejected classical street model that ,generates noise, dust and harmful gas emissions"[13]. Although conceived upon the ecological principles, as early as 1960's modernist ideas provoked numerous criticisms primarily directed towards urban zoning method which resulted in the breakdown of integrated and polyfunctional communities, applying monofunctional zoning strategies. [14]

In accordance to the then-current development of worldwide sustainability idea, numerous initiatives were taken in Yugoslavia in order to preserve and protect the environment during the 1970's. The SFRY Constitution, enacted in 1974, comprised a provision that ,it is the duty of socialist society to provide conditions for preservation and development of natural and other values of the environment that are of interest for a healthy, safe, and efficient life and work for both current and future generations“. [15] Since Brundtland Report published in 1987 defined sustainable development as the development that "meets the needs of the present without compromising the ability of future generations to meet their own needs"[16] we can take into consideration the progressive quality of ecological views within the socialist community of Yugoslavia. In the same period of the 1970s the City Secretariat for Urban Development and Environment, and the Institute for Criminological and Sociological Research conducted the study "Environmental Awareness and Self-Involvement of Working People and Citizens in Protecting and Improving the Natural Environment on the Territory of Belgrade". [17] The research showed that the development of environmental activities and awareness depended on different social conditions, but also the degree of personal development. Some of these conditions promoted the development of ecological activities and awareness, but there were also conditions that slowed down environmental activity and awareness, for example, as elements of uncontrolled development of the city, the contradiction between the directives and initiatives, the mismatch of formal and informal structures, undefined subject of responsibility, lack of environmental education, etc. [17]

Utopian models created during the 1960s by Yugoslav architects raised particular issues of environment humanization and the relationship between man and nature. Mutnjaković pointed out that the architect should be "a technologist with a strong sensitivity to human problems, he needs to create a modulator system, within which an infinite number of possible modulations in space and time are generated, and which makes each man the creator of his own environment, including the neighborhood environment, and the ambiance of society." [18] At the same time, Richter developed his hypothesis of system architecture. Starting from the fact that city growth necessitates the construction of architectural structures that greatly increase the density of both the population and functions, in order to enable this new ambient city structure, such construction necessarily requires a different method of planning and design. Richter founded the justification of environment synthesis in the socialist social system that sought a balanced relationship between the individual and the collective, and was interested in the man as an integrated biological and social being. As Richter noted, only those societies that addressed the life of the collective and individuals as an integral task have the ability to answer to the dictates of socialist time. The introduction of the term synthetic whole as a principle of life demanded a wider social and philosophical conception of the world as a totality, itself containing larger or smaller spatial and temporal units as totalities, as objects of integration and programs of synthesis. [19] On the other hand, Bogdanovic in his reflections on the 
crisis of the city, attempted to approach the problem from the aspect of historic city centers nuclei, which led to the associative thinking of a new vision of a center. He did not have a model or plan for new hypothetical centers, but said that the centers of a new urban-genetic approach should establish a relationship of deeper immediacy between man and nature, which in the epistemological sense determines the word symbol (sum-ballo), connecting these two divorced elements. [20]

As an expression of modern movement criticism in the period of 1970's and 1980's, Miloš Perović advocated urban revival proposing complete reconstruction of New Belgrade through the principles of traditional urban neighborhood design, the city economy, and thus spatial and programmatic sustainability. Perović asserted spontaneous urban growth processes and open city-transformation under influences of new social, economic and cultural development. [21]

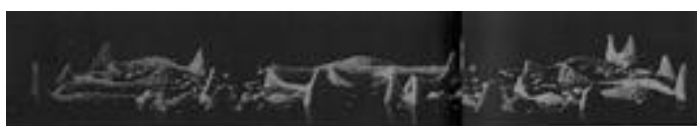

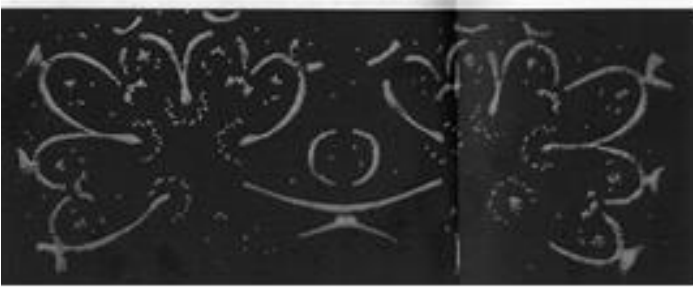

Fig. 1 Competition project „Biocity for Belgrade“, New Belgrade, 1965, Andrija Mutnjaković

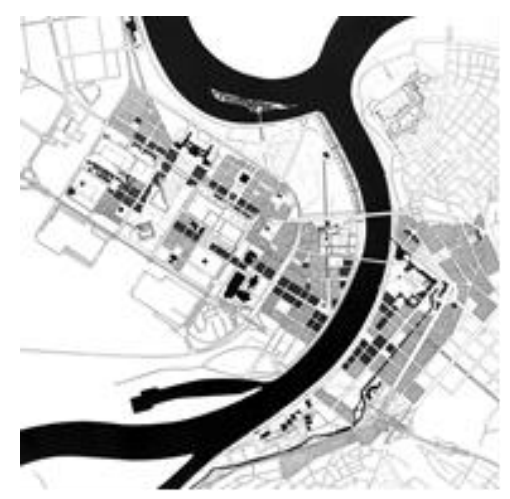

Fig. 2 Proposed reconstruction of New Belgrade and Sava amphitheater, 1981-1984, Miloš Perović

\section{The APARTMEnT as a RePresentative of the Socialist Housing Culture}

\subsection{The apartment as a spatial-functional framework of family living}

The criteria of transformation and defining changes in a lifestyle, the economic and social statuses, can clearly be interpreted through the housing space parameters. The changes in the functional organization and structure of housing units, the minimized measures and floor areas expressed in square meters during the design-making of housing spaces, as well as rationality when making a concept, should have represented "new" housing needs of the civil family in the socialist society.

In compliance with the new social relations and ideology, the society was responsible for providing every person, either as an individual or a member of a family group, with an apartment where, according to their needs and wishes, they would be able to develop their individual lives (complete isolation), and, simultaneously, take part in the family living as well. However, the socialist manner of producing social living and the standard was based on socially-limited material resources. Wishing to reach a higher level of the living standard 
as well as to form a new culture of collective multi-family housing, such material and organizational circumstances conditioned numerous researches conducted in the field of the organization of the housing unit and the system of prefabricated construction. The process of programming housing units was being based on the designing of the housing space which could satisfy a large number of assumed family situations. A variation of possible scenarios of using the same housing unit was being researched through the analyses of multi-functional housing spaces by superimposing compatible contents.

\subsection{Typology research - new concepts and principles of the housing units for socialist citizen}

"The Belgrade School of Housing" represents a synonym for the period of the intensive building of Yugoslavia between the 1970's and 1980's for the achieved quality of housing facilities, primarily from the aspect of functional organization. Developments and shifts towards a more humane society, a stateless status and more advanced culture of pluralism, as the backbone of the ideological system of SFRY, could be recognized in the aspirations of the designers of the "Belgrade apartment": with their organization and the way they were linked, these "typical units" ensured a higher level of development in terms of formation of the final assembly. [22]

Apart from a large number of competitions and projects, this time period was also characterized by a large number of theoretical papers focusing on the theme of housing, with a special emphasis on the theory of needs and the spatial-functional organization of the apartment. The retrospective of the development of the idea of the "elite" family living of the socialist citizen in collective housing conditions could provide insight of the aspects of the development of the spatial-functional concepts of the "Belgrade School of Housing".

- Organization conforms to the biological rhythm of the family (layouts structured into day and night zones)

- Dinning as the addition to extended circulation (gravity center of the apartment)

- Two centers, division by generations

- Circular connection

- Technical block as an anchor point

- Loggia as an anchor point

- Flexibility

- Multi-family housing individualization

- Dimensional coordination of functional organization and structural system

The reconsideration of the share of the day and the night zones in the housing unit from the aspect of the development and the balance of relationships within the family challenged the classical organization of space with an obvious division into the day zone and the night zone. The organizing of the housing unit into two centers (the one in the living zone and the other one in the zone of its extension - the family table) arose from a need for polarization, grouping and spending time associating within an age group, between the elderly generation and the younger generations. 


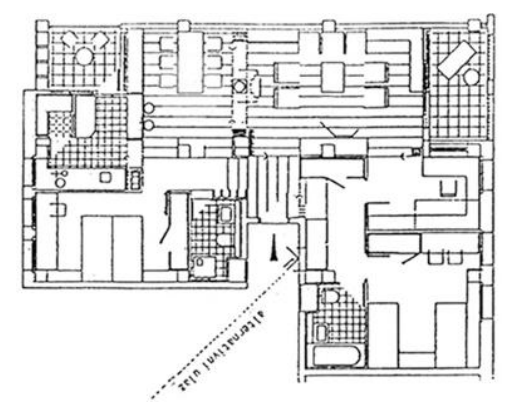

Fig. 3 Apartment in residential Settlement Cerak Vinogradi, Belgrade, the nineteen-eighties, architects: Prof. Darko Marušić, Melanija Marušić, Nedeljko Borovnica

In the analyzed time period, the circular connection, representing one of the main motifs in the apartment organization, was also an important theme because it was considered that it enabled the possibility of making choice of the direction, by which the apartment acquired a completely new quality and a higher usage value. This concept also contributed to the overlapping and permeation of the day and the night zones of the apartment and to a higher degree of the connectivity of different activities within the apartment. The apartment zones were no longer strictly polarized but the connection between them became more elastic and more direct.

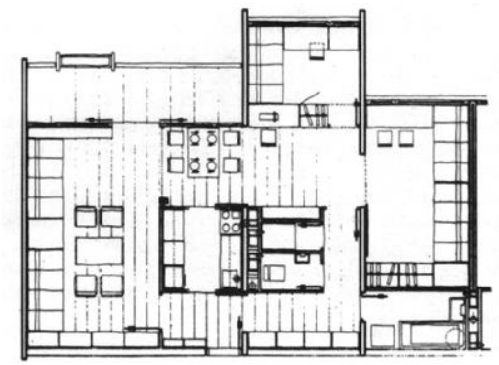

Fig. 4 Apartment in residential settlement Blok 22, Novi Beograd, 1968.

Arhitects: Božidar Janković, Branislav Karadžić, Aleksandar Stjepanović

When the structure of the apartment is concerned, the question of the gathering of the family members and the transformation of the day zone in the apartment is extremely sociologically significant. Due to restricted economic possibilities, the economical quality was frequently reached by the reduction in the number of standardized rooms, by anticipating a bed for one member of the family in the living-room. This issue was always topical as a subject matter of numerous laws, debates and discussions since it was considered to have a negative impact on social conditions and that is unacceptable as a standard since it does not enable gathering without interrupting. However, irrespective of the criticism and attempts to have that practice of project-making changed, all manuals for making projects for and constructing apartments, except for those manuals issued by the Ministry of Construction Works of the FPRY from the year 1947, anticipate the provision of a bed for one member of the family in the living-room, which also represented a room in the apartment which all family members shared with each other as well. 
As a result of numerous researches, and with an aim to find a solution to the mentioned problem, a proposal for an extended circulation as the central place for the gathering of the family members was presented in 1957. Using one part of the communication for the placing of the dining table, an economical space for the family members to gather was planned in the apartment. The family table is part of the tradition; however, in the new social conditions, it acquired a new role - the role of a multipurpose point - a regulator of the apartment's flexibility and its increased usage value. A more intimate connection between the kitchen and the extended circulation offered new possibilities to the family's shared living; an additional part in the form of a space for certain activities carried out inside the household (such as sewing, ironing, hobbies...), or the extended part of the communication for children to play and other things. All these were new points for living in the apartment, and, parallel with the orientation towards the two centers, they had a big influence on the formation of the socialist culture of multi-family collective living through the circular communication and the application of the principle of the growing apartment or the reducing apartment.

The emancipation and mass employment of women as well as the mechanization of jobs in the household significantly contributed to the shortening of the time needed for carrying out activities inside the home, which had as a consequence the reduction in the engagement of the woman within the household. Thus there was a separation of activities performed by all the members of the family, irrespective of their sex and age. The biggest transformations of the apartment were made within the space bearing the apartment's technical and hygienic functions.

The following ones are characteristic spatial-functional modifications:

- Shifting from the housing to the working kitchen;

- Dining space as the addition to extended kitchen and the emergence of an extended circulation; and

- Locating the space for managing the household in the center of the housing unit.

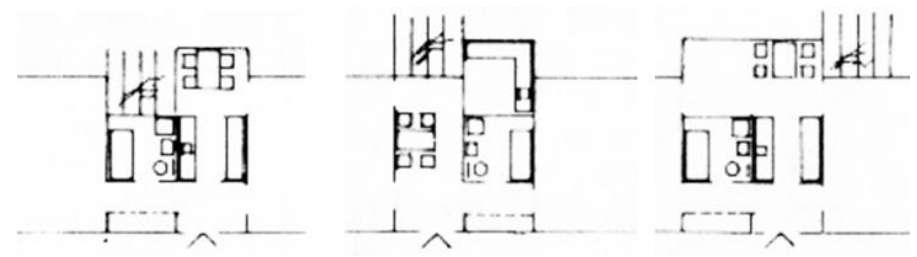

Fig. 5 Award-winning competition project, Block 61 and 62, New Belgrade, apartment variations, 1971. Architects D. and M. Marušić, M. Miodragović

As Jovanović-Nenadović points out, locating the technical block in the central part of the apartment so that it represents a sort of the apartment's constitutive motif - a command bridge the central point of controlling the management of the household became recognized as a characteristic approach to the organization of the apartment. [23]

\subsection{Equipment of the apartment}

The new housing spaces were supposed to represent a new culture and style of living of the socialist citizen, which certainly was contradictory to the until-then style of living of occupants who had come from various parts of the country and from environments of a 
different urbanity. The majority of the citizens had previously been living in single-family homes with a garden or in the so-called "salon apartments" with such elements as a diningroom, a boudoir, a library, a gallery, a salon and so forth between the wars. In the conditions of new apartments of minimized measures and floor spaces expressed in square meters which represented new housing needs of the civil family, there was no room for old habits and pieces of furniture. The style of life of a socialist citizen had to be redefined. With an aim to construct and organize apartments in as rational a manner as possible, together with designs made for apartments, architects frequently made proposals for the elements of the apartment's equipment as well. This equipment was most frequently project-made as modular in order to be economical and in accordance with the quantity of housing construction. Its goal was not to represent class-social differences and prestige, but to represent equality, rationality and economical quality in compliance with the dominant ideology and the new expected style of life of the working family.
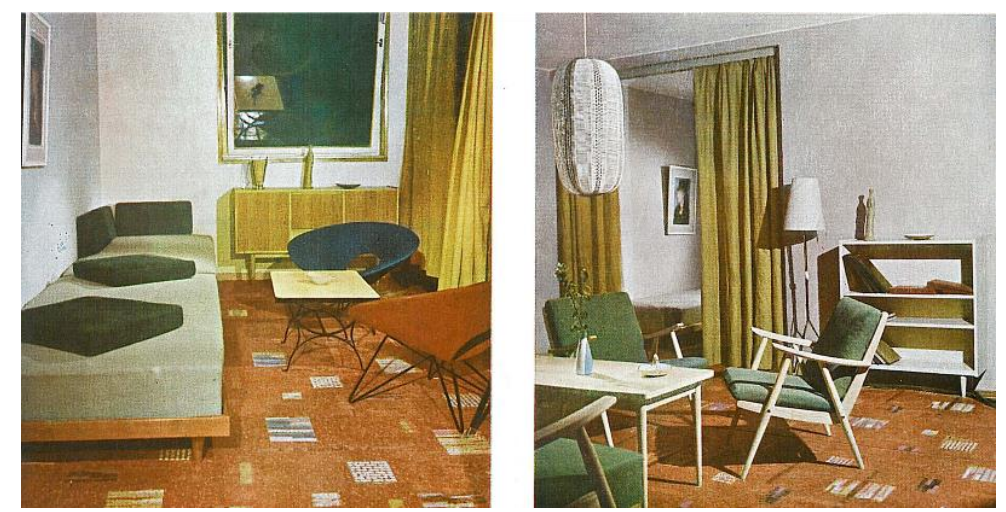

Fig. 6 Interior of New Belgrade typical apartment

Contemporary technological solutions had a big impact in the transformation of the existing and the construction of a new housing culture. Here we can highlight the influence of the elevator, which, together with contemporary construction techniques, enabled the construction of tall buildings, which had been beyond any possibility of realization in the conditions in Belgrade between the wars. The construction of tall buildings was certainly supposed to represent the progress, contemporariness and power of the then state's ideology. However, such a "new" culture of housing was not always approved of by the users.

\section{CONCLUSIONS}

The change of the state system and the dominant social goals as well as the redirection of the state's production from agricultural to industrial after the Second World War conditioned radical transformations of urban living. Within such an ideological framework, the policy of socialism was to create a new man - the socialist citizen. The main goal was to apply a new social structure to all the aspects of urban life, so that the absence of symbolic in planning and project-making was strongly being criticized. In compliance with the dominant ideology that the apartment should not be one of the characteristics of class differentiation any longer 
and a new expected style of life of the working family, the socialist apartment was supposed to represent equality, rationality and economical quality. However, the socialistic manner of the production of the social living and standard was being based on socially-limited material resources, which, in the stage one of the construction of apartments in socialism in the time period of the 1950's and the 1960's, resulted in low standards and restricted spatialfunctional solutions and apartments' equipment. Through an intensive competition practice in the next time period, in the 1970's and the 1980's, there was a rise in standards, which was primarily reflected in the development of the concept of the "elite" family living of the socialist citizen in the conditions of collective housing.

Acknowledgement. The paper is a part of the research done within the projects TR36034 and OI179048 funded by the Ministry of Education, Science and Technological Development of the Republic of Serbia.

\section{REFERENCES}

1. Љ. Благојевић, Стратегије модернизма у планирању и пројектовању урбане структуре и архитектуре Новог Београда: период концептуалне фазе од 1922. до 1962.године (Strategies of Modernism in the Planning and Construction of Urban Structure and Architecture of New Belgrade: period of conceptual phase since 1922. up to 1962), Београд: Архитектонски факултет, 2004, p. 93.

2. С. Вујовић, Људи и градови (Реople and cities), Београд: Филозофски факултет, 1990, p. 96.

3. M. Petrović, Stambena politika u socijalističkom društvenom sistemu (Housing policy in the socialist system), In: Sociologija stanovanja (Sociology of housing), Beograd: Institut za sociološka istraživanja i Filozofski fakultet, 2004, pp. 67-68.

4. B. Milojević, "Urban development and influential factors on urban form of towns in Bosnia and Herzegovina in the period of socialism and transition: Case study of Banjaluka and Trebinje", Facta universitatis - series: Architecture and Civil Engineering, 11(3),2013, pp. 237-249., DOI: 10.2298/FUACE1303237M

5. П. Марковић, Између истока и запада (Between East and West), Београд: Службени лист, 1996, pp. 296-297.

6. Скромни стан - и за сутра (Modest apartment - and for tomorrow), In: Економска политика (Economic policy), 1958, p. 279; Какав је стан потребан градској породици, In: Политика, 20.03.1956. Cited in Марковић, Између истока и запада, р. 300.

7. Л. Јовановић-Ненадовић, Концепција пројектовања стамбених јединица у Новом Београду анализа конкурсних решења у периоду 1966-1975. године (The conception of the design of housing units in New Belgrade - the analysis of competition solutions in the period between 1966-1975), Београд: Архитектонски факултет, 2011, р. 13.

8. Housing blocks which the Army constructed for their needs in specified period between 1965. and 1973. year are: 33, 37, 38, 29, 22, 23, and partly blocks 9a-11c and 70 and 45. Sеe Л. Јовановић-Ненадовић, Концепција пројектовања стамбених јединица у Новом Београду (The conception of the design of housing units in New Belgrade), p. 30.

9. Data from the Statistical Yearbook for the city of Belgrade in period between 1970-1980.

10. H. Hertzberger, Forum 2/1962. See in: A. Lüchinger, Structuralism in Architecture and Urban Planning, Stuttgart: Karl Kramer, 1981, p. 55.

11. R. Williams, Marxism and Literature, Oxford: Oxford University Press, 1977.

12. C. Hermansen Cordua, Manifestoes and transformations in the early modernist city, Farnham, Surrey, England; Burlington, Vt.: Ashgate Pub. Co., 2010.

13. $\breve{S}$. Fransoaz, Urbanizam, utopija stvarnost (Urbanism, Utopia and Reality), Belgrade: Gradevinska knjiga, 1978.

14. J. Ristić Trajković, D. Stojiljković and D. Ćirić, Proceedings of the 12th Internacional Docomomo Conference: The Survival of Modern From Coffee Cup to Plan, Docomomo Finland, 2013, pp. 381-388.

15. D. Marković, Socijalna ekologija (Social Ecology), Belgrade: Zavod za udžbenike i nastavna sredstva, 1986, p. 133. 
16. United Nations, "Report of the World Commission on Environment and Development", General Assembly Resolution 42/187, 11 December 1987.

17. Đ. Đurović, „Ekološka svest i samoupravno angažovanje radnih ljudi i građana u zaštiti i unapređenju prirodne sredine na teritoriji Beograda“ (Environmental Awareness and Self-Involvement of Working People and Citizens in Protecting and Improving the Natural Environment on the Territory of Belgrade), Urbanizam Beograda br. 59-60, p. 17.

18. A. Mutnjaković, Endemska arhitektura (Endemic architecture), Osjek: Revija, 1987, p. 59.

19. V. Richter, Sinturbanizam (Sinturbanism), Zagreb: Mladost, 1964, p. 86.

20. B. Bogdanović, Urbs \& Logos: ogledi iz simbologije grada (Urbs and Logos: essays on the symbolism of town), Niš: Gradina, 1976, p. 32.

21. M. Perović, Iskustva prošlosti (Lessons of the Past), Belgrade: Građevinska knjiga, 1985.

22. A. Ignjatović, „Mit o trojanskom konju 'Beogradska škola arhitekture' (Myth of the Trojan Horse: 'Belgrade School of Architecture'), in Istorija umetnosti u Srbiji XX vek. Realizmi i modernizmi oko Hladnog rata (History of Art in Serbia, XX Century: Realisms and Modernism around the Cold War), (eds.) M. Šuvaković, N. Daković, A. Ignjatović, V. Mikić, J. Novak i A. Vujanović, 421-426. Beograd: Orion Art i Katedra za muzikologiju Fakulteta muzičke umetnosti, 2012.

23. Л. Јовановић-Ненадовић, Концепција пројектовања стамбених јединица у Новом Београду (Тһе conception of the design of housing units in New Belgrade), p. 86.

\section{UTICAJ SOCIJALISTIČKE IDEOLOGIJE NA KONCEPCIJU VIŠEPORODIČNOG STANOVANJA: NOVI URBANI PEJZAŽ I TIPOLOŠKI MODELI STAMBENIH JEDINICA}

Rad istražuje ideološke uticaje na urbani pejzaž, kao i na projektovanje tipoloških modela stambenih jedinica izgrađenih u Beogradu u periodu socijalističkog sistema. Posle Drugog svetskog rata, jedan od glavnih strateškh ciljeva socijalizma bio je rešavanje stambenog problema Beograda izgradnjom moderne, serijski proizvedene i ekonomične stambene arhitekture. Period intenzivne stambene izgradnje u Beogradu u periodu od samoupravnog socijalizma se prvenstveno povezuje sa ostvarenim kvalitetom stanovanja u smislu humanizacije okruženja i funkcionalne organizacije stambenih jedinica. Ovaj rad istražuje nove koncepte i principe stambene arhitekture sa akcentom na uticaju prostorno-funkcionalane transformacije stana na stil života i formiranje nove socijalističke kulture stanovanja. Imajući u vidu da je problem stanovanja interdisciplinaran, transformacija se istražuje kroz uspostavljanje uzročno-posledičnih veza između ideoloških društvenih promena, kulture stanovanja, tehničko-tehnoloških kriterijuma $i$ prostorno- funkcionalne strukture stambene jedinice. Moderna stambena arhitektura i urbanizam su posmatrani kao reprezentacija društvenih, političkih, ekonomskih, demografskih i kulturnih promena u periodu socijalizma.

Ključne reči: višeporodično stanovanje, socijalistička ideologija, humanizacija okruženja, urbani pejzaž, stambena kultura, Beograd 